\title{
Copper deposition at segmented, reticulated vitreous carbon cathode in Hull cell
}

\author{
R. C. Tangirala ${ }^{1}$, C. T. J. Low ${ }^{1}$, C. Ponce-de-León ${ }^{11}$, S. A. Campbell ${ }^{2}$ and F. C. \\ Walsh $^{1}$
}

The electrodeposition of copper from an acid sulphate solution has been studied in a Hull cell fitted with four types of cathode; a carbon plate or a reticulated vitreous carbon (RVC) sheet was used either in a continuous or segmented form. The rates of mass transport to the planar plate and RVC electrodes have been compared in static and stirred electrolytes containing 50, 75 and $100 \mathrm{mmol} \mathrm{dm}^{-3} \mathrm{CuSO}_{4}$ in $0.5 \mathrm{~mol} \mathrm{dm}^{-3} \mathrm{Na}_{2} \mathrm{SO}_{4}$ at $\mathrm{pH} 2$ and $298 \mathrm{~K}$. The cathodes were divided into 10 equal sections and current vs. potential curves were obtained for each section at a constant current up to $140 \mathrm{~mA}$. The current distribution over the cathodes followed a logarithmic decay with distance along the cathode; segments nearest to the anode experienced the highest rate of copper deposition.

Keywords: Copper deposition, Current and potential distributions, Hull cell, Limiting current, Reticulated vitreous carbon, Three-dimensional electrodes

\section{List of symbols}

a Constant in equation (1)

$A$ Geometric electrode area, $\mathrm{m}^{2}$

$b$ Constant in equation (1)

$c$ Concentration of cupric ions, $\mathrm{mol} \mathrm{cm} \mathrm{cm}^{-3}$

$E_{\mathrm{c}}$ Potential of the cathode, $\mathrm{V}(\mathrm{SCE})$

$E_{\text {cell }}$ Cell voltage, $\mathrm{V}$

$F$ Faraday constant $\left(96485 \mathrm{C} \mathrm{mol}^{-1}\right), \mathrm{C} \mathrm{mol}^{-1}$

I Total current, A

$I_{\mathrm{L}} \quad$ Limiting current for copper deposition, A

$I_{\mathrm{Cu}}$ Current for copper deposition, A

$j$ Current density, $\mathrm{A} \mathrm{cm}^{-2}$

$j_{\mathrm{L}}$ Limiting current density for copper deposition, $\mathrm{A} \mathrm{cm}^{-2}$

$k_{\mathrm{m}} \quad$ Mass transport coefficient, $\mathrm{cm} \mathrm{s}^{-1}$

$L$ Overall length of the cathode, $\mathrm{cm}$

$M_{\mathrm{Cu}}$ Molar mass of copper $\left(63.54 \mathrm{~g} \mathrm{~mol}^{-1}\right)$, $\mathrm{g} \mathrm{mol}^{-1}$

$q_{\mathrm{Cu}}$ Electrical charge for copper deposition, C

$R$ Electrical resistance, $\Omega$

$t$ Time, $\mathrm{s}$

$w_{\mathrm{Cu}} \quad$ Mass of copper deposited, $\mathrm{g}$

$x$ Distance along the cathode from the end nearest to anode, $\mathrm{cm}$

$z$ Number of electrons in the electrode reaction

$\phi_{\mathrm{Cu}}$ Current efficiency for copper deposition

\footnotetext{
${ }^{1}$ National Centre for Advanced Tribology, Electrochemical Engineering Laboratory School of Engineering Sciences, University of Southampton, Highfield, Southampton SO17 1BJ, UK

${ }^{2}$ Applied Electrochemistry Group, School of Pharmacy and Biomedical Sciences, University of Portsmouth, Portsmouth PO1 2DT, UK

*Corresponding author, email capla@soton.ac.uk
}

\section{Introduction}

Current and potential distributions in electrochemical cells have been intensely studied due to their importance in cell design and electrodeposition processes. ${ }^{1-3}$ Cell design and construction requires careful attention to electrode geometry in order to achieve optimal current and potential distributions. In metal deposition, inadequate consideration of cell geometry could lead to a non-uniform deposit thickness composition. Planar and three-dimensional electrodes have been used for a number of reactions such as the reduction of $\mathrm{Ag}^{+}$, $\mathrm{Cu}^{2+}, \mathrm{Ni}^{2+}$ and $\mathrm{Pb}^{2+}$ and their current and potential distributions have been considered elsewhere. ${ }^{4-9}$

The successful electrodeposition of metals requires well characterised electrochemical cells where appearance, hardness and corrosion resistance of deposits can be carefully controlled. Inexpensive materials coated with a metal layer can acquire properties which are otherwise difficult and expensive to achieve.

The properties of electrodeposits depend on factors such as electrolyte composition, purity, complexing agents, temperature, additives, current density, electrolyte flow, cell geometry and $\mathrm{pH}$. During a continuous electroplating process, these parameters are monitored by volumetric, gravimetric and instrumental methods and then adjusted to maintain the appropriate bath composition. The electroplated layer must then exhibit satisfactory properties according to the proposed application, e.g. strength, corrosion resistance, brightness, durability, uniform thickness, smooth deposits and uniform texture. Practical measurements to evaluate the electroplating conditions require a test cell with a well defined geometry; some comparative tests can be made in a simple parallel plate or in other electrochemical test cells. For example, the Assaf cell ${ }^{10,11}$ 
consists of a $0 \cdot 25 \mathrm{dm}^{2}$ metal plate electrode attached to a polyethylene sheet at a distance of $\square 4 \mathrm{~cm}$. In this cell, the front plate faces the anode and experiences high current densities while the back of the plate faces the plastic board and its current density is low. A more defined flow regime in electrochemical cells can be obtained via a rotating disc electrode, ${ }^{12,13}$ a rotating cylinder electrode ${ }^{14,15}$ or a rotating cylinder Hull cell. ${ }^{16-18}$

Many practitioners use the classic Hull cell for quality control of electroplating baths. The device usually consists of a cell of $267 \mathrm{~cm}^{3}$ electrolyte volume having a trapezoidal cross-section with an oblique angle cathode structure with respect to the anode. ${ }^{19-22}$ At a fixed current, the potential of the working electrode depends on the distance from the anode and the optimal current density distribution on the working electrode can be determined experimentally. Experiments in the Hull cell can be carried out rapidly before the electroplating process for a variety of bath compositions, assisting the determination of useful current densities, additive concentration, impurity effects and throwing power capability in a single, rapid experiment. The deposited metal or alloy can be analysed by comparing the appearance, thickness, phase composition, hardness, throwing and distribution of metals during deposition. The gradual variation of the distance between anode and cathode in this cell allows the determination of the optimal conditions for deposition. The Hull cell is widely used for troubleshooting and process development, electroplating of metals and for rapid screening tests of addition agents. ${ }^{23}$ The empirical relationship between the current density at the cathode and its length can be expressed as

$$
j=I(a-b \log x)
$$

where $I$ is the current density and $x$ is the distance along the cathode from the end nearest to the anode; $a$ and $b$ are two experimental constants. This correlation is useful to determine the optimal bath electroplating conditions in larger cells. ${ }^{24}$

The surface finishing industry produces a large amount of effluents containing heavy metal ions from electrolytic baths and rinse waters. ${ }^{25}$ Electrolysis is one of the most common methods employed to remove the unused metals before discharging the effluent. However, in most cases, the metal concentration in these baths is very low $(<1 \mathrm{ppm})$ and an efficient cell configuration, with large surface area electrodes, is required.

Three-dimensional cathodes provide a high surface area for efficient removal of metal ions from low concentration solutions. Over the last three decades, many electrolytic recovery processes have used an open cell porous structure, such as the reticulated vitreous carbon (RVC) as an electrode material. The high porosity and hence low electrolyte pressure drop, low cost, reasonable electrical conductivity, self-supporting rigid matrix and easy fabrication make the RVC the appropriate electrode material for metal recovery. ${ }^{26,27}$ The electrodes have been used to remove $\mathrm{Cu}^{2+}, \mathrm{Ni}^{2+}$, $\mathrm{Ag}^{+}$, and $\mathrm{Pb}^{2+}$ among other metal ions from wastewater processes such as photographic, printed circuits and battery industries. Detailed descriptions of the properties and applications of RVC can be found in the literature. ${ }^{28-33}$
The classic Hull cell, which utilises a continuous planar metal substrate cathode, has been widely described in the literature. ${ }^{19,24,34-38}$ Segmented cathodes have also been used in the Hull cell for zinc electrowinning on aluminium. The cathode was divided in 10 electrically isolated segments which allowed the calculation of the current densities across the cathode and the study of the zinc morphology in each electrode by SEM and X-ray analysis. ${ }^{35}$ The purpose of this paper is to demonstrate the use of a Hull cell with a planar carbon cathode and segmented planar and three-dimensional RVC cathodes ${ }^{33}$ and compare their performance during the removal of copper ions. Current $v s$. potential curves were monitored during the deposition of copper from dilute solutions in a sulphate electrolyte at $\mathrm{pH} 2$.

\section{Electrode reactions and polarisation}

The primary cathode reaction during the electrolysis of copper sulphate on the carbon cathodes was copper deposition

$$
\mathrm{Cu}^{2+}+2 \mathrm{e}^{-} \rightarrow \mathrm{Cu}^{0}
$$

Hydrogen evolution could occur as a secondary reaction

$$
2 \mathrm{H}^{+}+2 \mathrm{e}^{-} \rightarrow \mathrm{H}_{2}
$$

A small amount of oxygen reduction is also possible due to dissolved oxygen

$$
\mathrm{O}_{2}+4 \mathrm{e}^{-}+4 \mathrm{H}^{+} \rightarrow 2 \mathrm{H}_{2} \mathrm{O}
$$

A copper anode dissolves in order to maintain the concentration of $\mathrm{Cu}^{2+}$ constant

$$
\mathrm{Cu}^{0}-2 \mathrm{e}^{-} \rightarrow \mathrm{Cu}^{2+}
$$

The use of soluble copper anode ensured a constant $\mathrm{Cu}^{2+}$ level in the electrolyte. When the cell was not used, the electrodes were removed from the solution to prevent open circuit dissolution of copper.

In a current $v$. potential curve of copper deposition, three main regions can be identified: ${ }^{14}$ mixed control, mass transport control and secondary reaction regions, normally hydrogen evolution. In this work, the current $v$. potential curves were obtained from the application of constant currents, which covered the three regions. At the mass transport controlled region, the potential of each electrode remains approximately constant and the limiting current can be expressed as

$$
I_{\mathrm{L}}=A z F k_{\mathrm{m}} c
$$

where $I_{\mathrm{L}}$ is the limiting current, $A$ is the electrode area, $z$ is the number of electrons, $F$ is the Faraday constant, $k_{\mathrm{m}}$ is the mass transport coefficient and $c$ is the concentration of cupric ions.

\section{Experimental}

\section{Hull cell}

A conventional and transparent acrylic Hull cell (Canning) was used. The cell, typically having an electrolyte capacity of $267 \mathrm{~cm}^{3}$, has a trapezoidal cross-section with a rectangular side of $7 \cdot 3 \mathrm{~cm}$ length (where the anode was placed) and an oblique side of $10.6 \mathrm{~cm}$ length (where the working electrode was located). The longest distance between the anode and cathode sides was $13.7 \mathrm{~cm}$, while the shortest distance was $5 \cdot 3 \mathrm{~cm}$. The cell was $6 \cdot 5 \mathrm{~cm}$ in height and was fitted 
with carbon cathodes on the oblique side and a planar $(0 \cdot 1 \mathrm{~cm}$ thick) copper plate anode on the opposite side. Figure $1 a$ shows the segmented RVC cathodes on the oblique side of the cell and the electrical circuit.

\section{Electrodes}

The anode was a copper plate of dimensions $10 \cdot 5 \times$ $10.5 \times 0.05 \mathrm{~cm}$ with an immersed area of $\sim 47 \mathrm{~cm}^{2}$. The working electrodes occupied the whole oblique side area of the Hull cell (Fig. 1a). Four different carbon cathode configurations were used:

(i) a planar carbon electrode of $10.5 \times 10 \times 0.5 \mathrm{~cm}$ dimensions

(ii) a segmented electrode consisted of 10 carbon planar plates of $11 \times 0.8 \times 0.35 \mathrm{~cm}$ each

(iii) a single piece of 80 pores per inch (ppi) reticulated vitreous carbon of $10.5 \times 10 \times 0.2 \mathrm{~cm}$ dimensions

(iv) a segmented electrode consisting of a set of 10 RVC electrodes of $80 \mathrm{ppi}$, each of $5 \mathrm{~cm}$ length, $0.8 \mathrm{~cm}$ width and $0.2 \mathrm{~cm}$ thickness.

The RVC material was glued with a graphite adhesive to a carbon plate of the same dimensions as in (ii). The segmented electrodes were evenly distributed on the oblique side of the cell and fixed to a bakelite plate machined with 10 groves to fit each individual electrode and to ensure that they did not contact each other. Figure $1 b$ shows both, a front and a top views of the RVC segmented electrodes and their dimensions, while Fig. $1 c$ shows a scanning electron micrograph image of the uncoated 80 ppi RVC material used. This image shows the open pore structure, the skeletal (trigonal) struts responsible for electrical conductivity and the nodes at their junction. The planar carbon electrodes, described as (i) and (ii) above, were polished using 1200 grade silicon carbide paper until a mirror-like surface finish was obtained. The back and sides of the electrodes were coated with a non-reactive insulating acrylic resin to ensure that these areas remained inactive. The solution level in all experiments was $4.5 \mathrm{~cm}$ from the bottom of the cell. Considering a surface area per unit volume of $50 \mathrm{~cm}^{2} \mathrm{~cm}^{-3}$ for an 80 ppi RVC material ${ }^{33}$ and that the volume of the RVC cathode was $9.5 \mathrm{~cm}^{3}$ $(10 \cdot 5 \times 4 \cdot 5 \times 0 \cdot 2 \mathrm{~cm})$, the surface area of the continuous RVC cathode was $475 \mathrm{~cm}^{2}$. Similarly, the volume of each segment of the RVC electrode immersed into the solution was $0.72 \mathrm{~cm}^{3}(4.5 \times 0.8 \times 0.2 \mathrm{~cm})$ and the area immersed in the electrolyte was $36 \mathrm{~cm}^{2}$ for each RVC segment.

\section{Electrolytes}

Three different concentrations of $\mathrm{CuSO}_{4}$ were tested: 50 , 75 and $100 \mathrm{mmol} \mathrm{dm}^{-3}$ in $0.5 \mathrm{~mol} \mathrm{dm}{ }^{-3} \mathrm{Na}_{2} \mathrm{SO}_{4}$ at pH 2 and $298 \mathrm{~K}$. The electrolytes were prepared with deionised water and reagent grade chemicals (Fischer Scientific, Pittsburgh, PA, USA).

\section{Experimental procedure}

Electrolysis of cupric ions was carried out by applying constant currents of up to $140 \mathrm{~mA}$ to the carbon plate and the potential was measured at 10 points distributed along the cathode as described below. The electrodeposition of copper onto the planar carbon and RVC segmented electrodes described in the previous section was carried out at a cell current up to $110 \mathrm{~mA}$ in separate experiments with static and stirred solutions. An additional electrodeposition was carried out on a

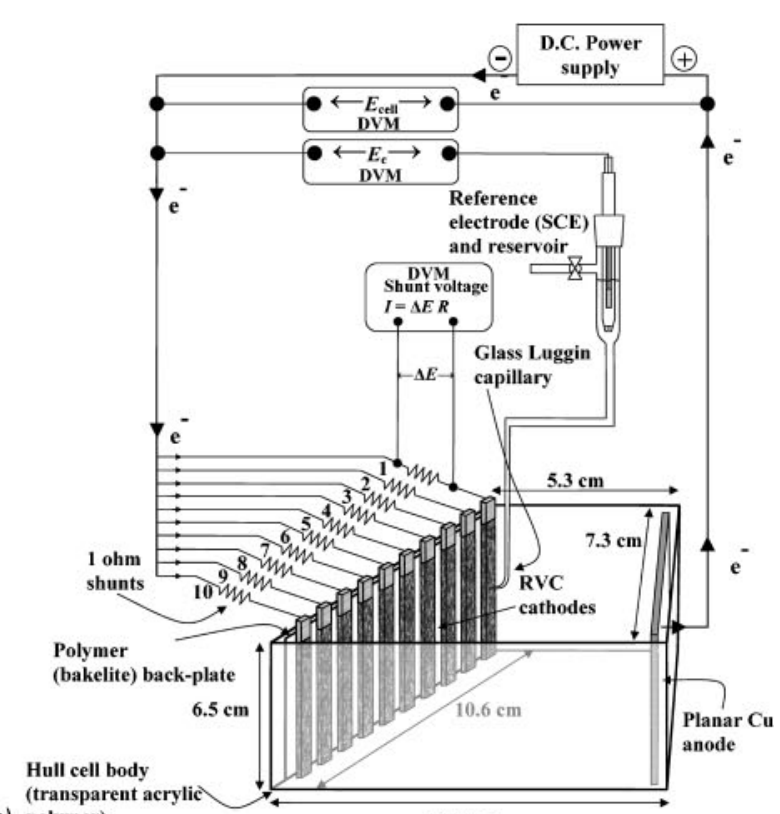

(a) polymer)
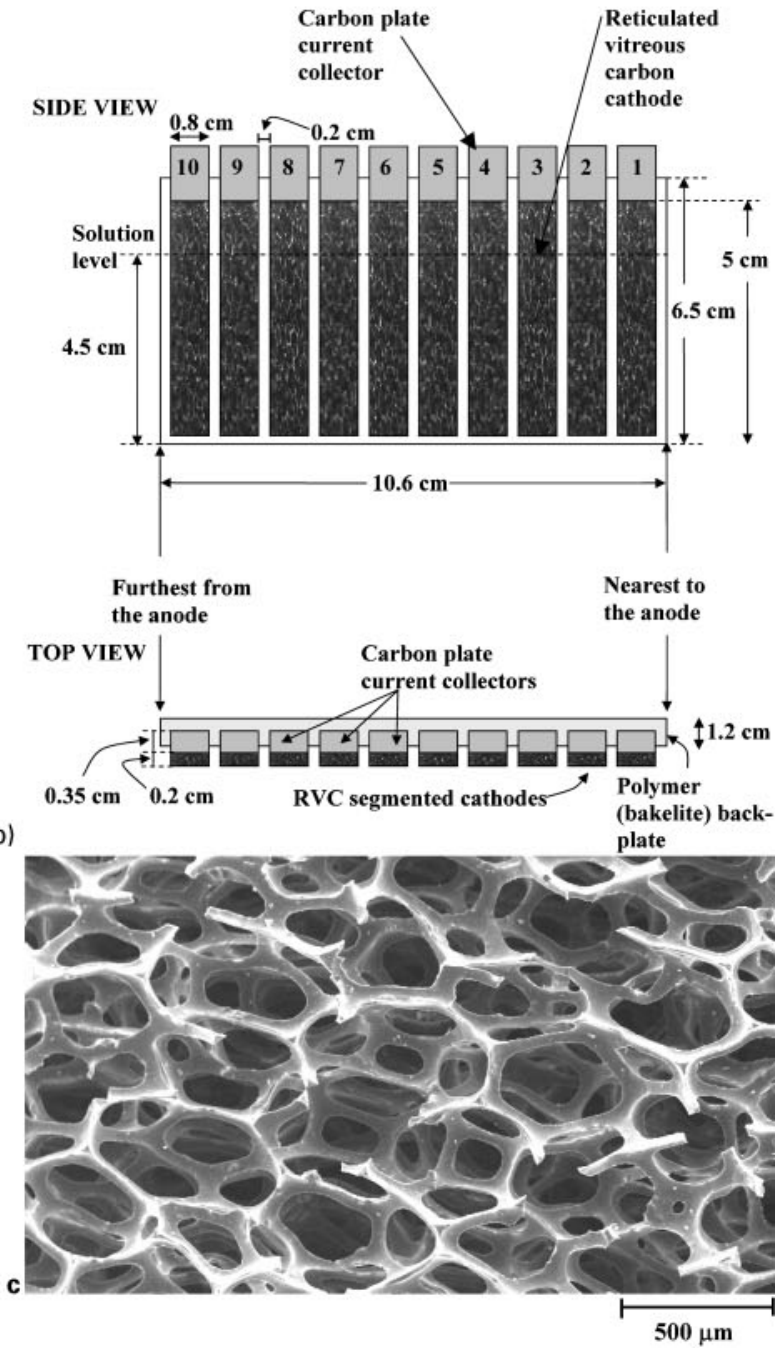

a general arrangement and electrical circuit (DVM: digital voltmeter); $b$ front view of segmented cathode arrangement located in oblique side of cell; $c$ scanning electron microscopy photo of 80 ppi RVC

1 Hull cell 

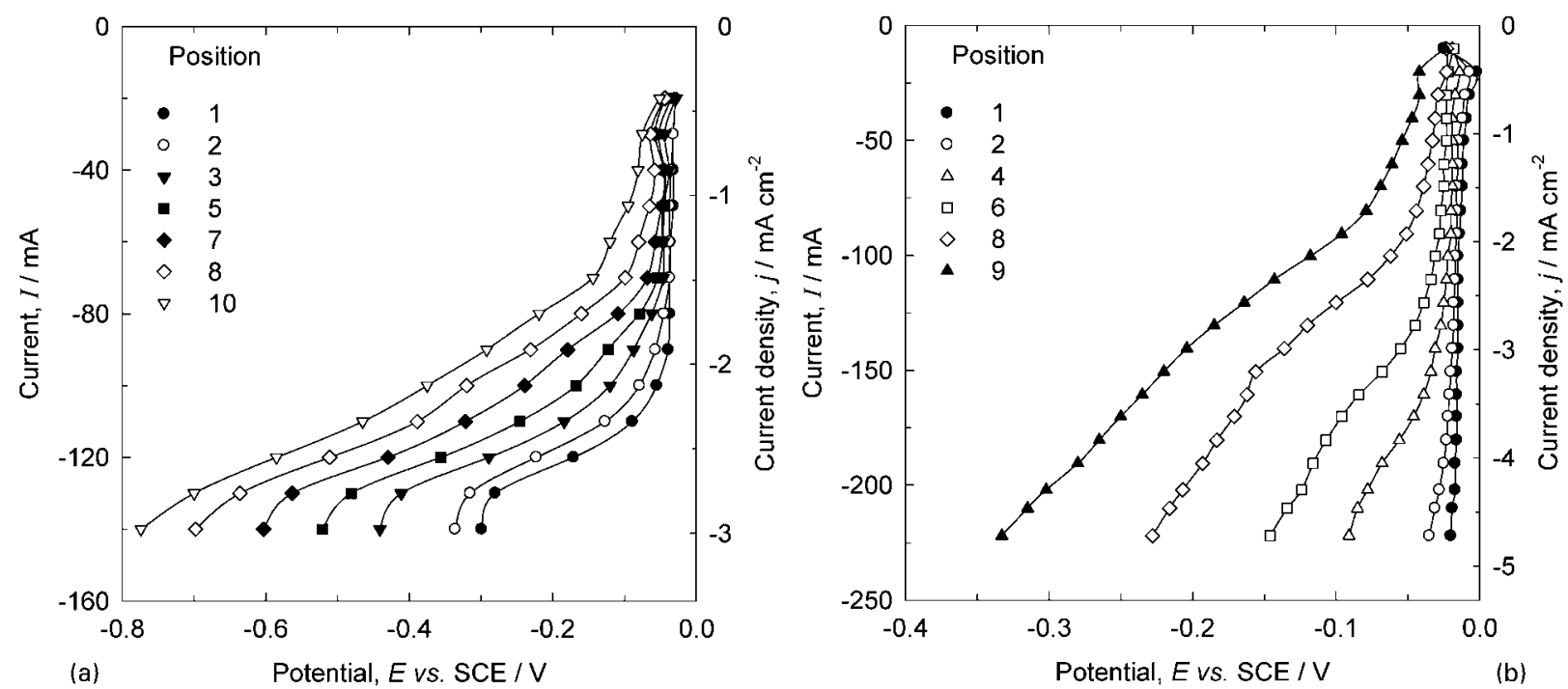

$a$ static electrolyte; $b$ stirred electrolyte

2 Current $v$. potential curves for deposition of $\mathrm{Cu}$ from $50 \mathrm{mmol} \mathrm{dm}{ }^{-3} \mathrm{CuSO}_{4}$ in $0.5 \mathrm{~mol} \mathrm{dm}^{-3} \mathrm{Na}_{2} \mathrm{SO}_{4}$ at pH 2 electrolyte on planar carbon plate: positions 1-10 correspond to points distributed evenly along length of cathode

single piece of $\mathrm{RVC}$ at $2 \mathrm{~A}$ in order to observe the morphology of the copper deposits at different positions along the cathode. The potential of the cathodes was measured at each current against the standard calomel reference electrode (SCE) with 10 Luggin capillaries located at about $1-2 \mathrm{~mm}$ from the surface of the cathodes and evenly distributed along the oblique side of the Hull cell. For clarity, Fig. $1 a$ shows the position of the Luggin capillary in front of one position on the segmented electrode; the potentials of the other electrodes were measured at similar points (not shown). Care was taken to locate the Luggin capillary probes at the same point in all experiments. The ten Luggin capillaries were connected to a fluid manifold which allowed the potential of each position or electrode $v$. the SCE reference to be monitored $( \pm 1 \mathrm{mV})$ with a high impedance digital voltmeter (Fluke 23 Series II Digital). The currents were applied with a Hi-Tek potentiostat operated in the galvanostatic configuration. The currents flowing through each segmented electrode were monitored by the voltage drop across a $1 \Omega$ shunt connected in series to each segmented electrode. Figure $1 a$ also shows the position of each shunt in relation to the segmented electrodes and the potential measurement for electrode 1 . The potential drop across the shunts for the other electrodes was measured in a similar manner with a high impedance digital voltmeter.

The current efficiency for copper deposition on the segmented carbon electrodes (both planar and reticulated) was evaluated at constant current for $20 \mathrm{~min}$. The current through each segment was monitored. Following the electrodeposition, the copper deposited on each cathode was dissolved in $20 \mathrm{~cm}^{3}$ of $1 \mathrm{~mol} \mathrm{dm}^{-3}$ nitric acid and the $\mathrm{Cu}^{2+}$ concentration was determined by atomic absorption spectrophotometry (AAS). The charge passed through each electrode was compared to that expected (Faraday's laws) to deposit the amount of copper determined by the analytical method (see the section on 'Experiments with 10 segment reticulated carbon vitreous cathodes').

\section{Results and discussion}

\section{Experiments with planar carbon cathode}

The electrode potential of the planar cathode electrode was monitored during the application of constant current at 10 different points, evenly distributed along the width of the electrode as shown in Fig. 1 for the case of segmented electrodes. Figure 2 shows the current $I v$. potential $E$ curves for copper deposition from a solution containing $\mathrm{Cu}^{2+}$ ions at $50 \mathrm{mmol} \mathrm{dm}{ }^{-3}$ concentration at static (Fig. 2a) and stirred (Fig. 2b) conditions. Each curve represents the current $v$. potential characteristics at a fixed cathode position. Position 1 was the closest to the anode while position 10 was the furthest. All the curves in the static solution (Fig. 2a) show a sloped region which can be identified as the mass transport controlled region where the change of current with potential was the lowest. Position 1 shows a short mass transport region between -0.090 and $-0 \cdot 220 \mathrm{~V}(\mathrm{SCE})$ at currents of -110 and $-130 \mathrm{~mA}$ respectively. The potential range of the mass transport region became wider as the position between anode and cathode increased but the currents were slightly lower. At the furthest position 10, a long mass transport controlled region between -0.220 and $-0.580 \mathrm{~V}$ (SCE) with currents between -80 and $-150 \mathrm{~mA}$ respectively, was observed.

Under stirred conditions, similar behaviour can be observed but the limiting current regions are shorter and steeper compared with the static conditions and are more difficult to determine. The current at the electrode positions 1 and 2 (closest from the anode) shows a value of around $-220 \mathrm{~mA}$ at potentials of -0.02 and $-0.04 \mathrm{~V}(\mathrm{SCE})$ respectively without reaching mass transport controlled conditions. At positions 8 and 9 (furthest to the anode), a steep limiting current plateau appears with current between -90 and $-130 \mathrm{~mA}$ and potentials of between $-0 \cdot 100$ and $-0 \cdot 20 \mathrm{~V}(\mathrm{SCE})$ respectively.

In the experiments containing 75 and $100 \mathrm{mmol} \mathrm{dm}^{-3}$ $\mathrm{Cu}^{2+}$ ions concentration, the $I v . E$ curves at both static 

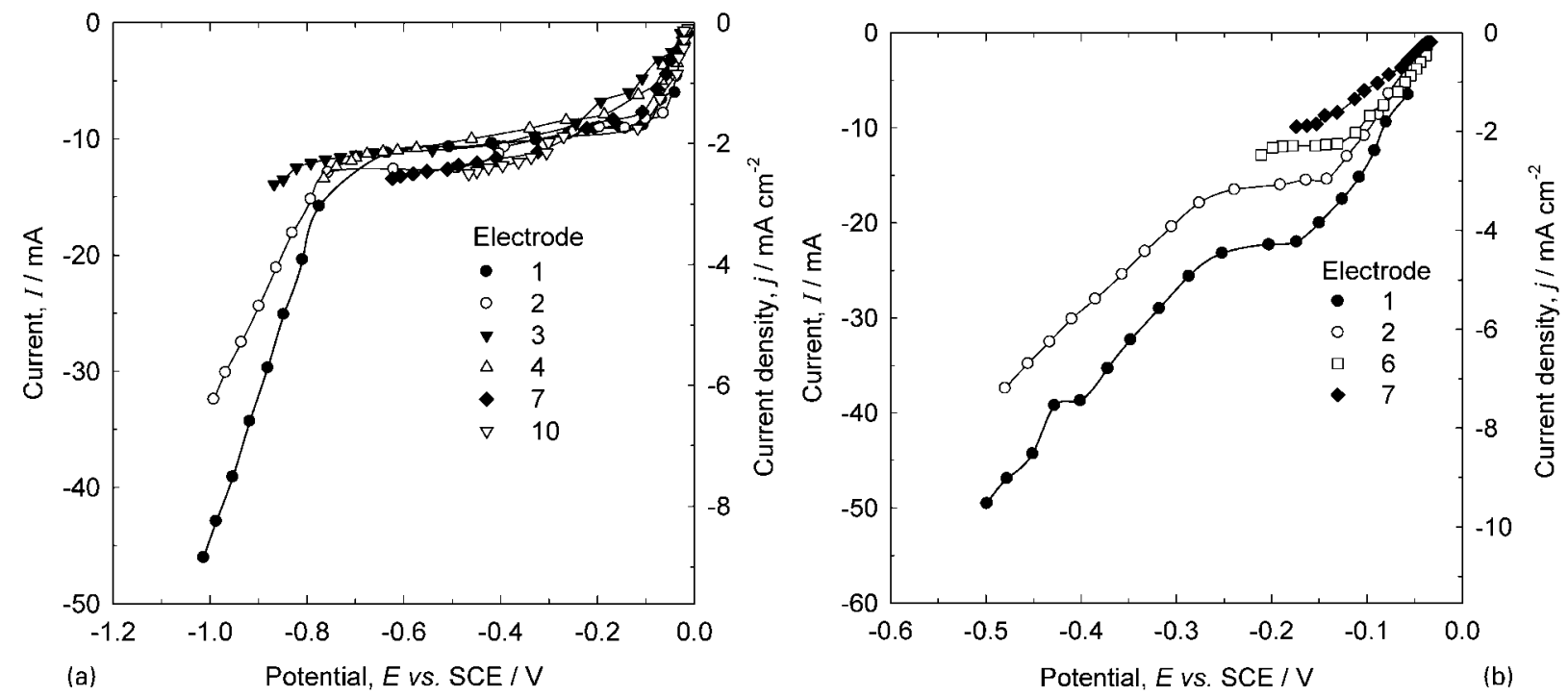

3 Current $v$. potential curves for deposition of $\mathrm{Cu}$ ions from $50 \mathrm{mmol} \mathrm{dm}{ }^{-3} \mathrm{Cu}^{2+}$ in $0.5 \mathrm{~mol} \mathrm{dm}^{-3} \mathrm{Na}_{2} \mathrm{SO}_{4}$ at $\mathrm{pH}_{2}$ on segmented planar carbon electrodes under $a$ static and $b$ stirred electrolyte conditions

and stirred conditions show similar trend as shown for the $50 \mathrm{mmol} \mathrm{dm}{ }^{-3}$ solution explained above.

For the planar electrode, the effect of high mass transport conditions can be seen by the magnitude of the current at the positions closest to the anode. At a potential of $-0.031 \mathrm{~V}(\mathrm{SCE})$, the current in the stirred

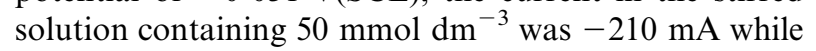
in the static solution, it was only $-80 \mathrm{~mA}$. The positions nearest to the anode became heavily coated under stirred conditions while the deposit was less dense and opaque on the positions furthest from the anode. Table 1 shows the approximate values of the current and voltage in the mass transport controlled region at the 10 different positions for the three concentrations employed under static and stirred electrolyte conditions. These values were obtained by visual estimation of the mass transport controlled region. The values show that for the same concentration of copper, the mass transport controlled region appeared at higher potentials and high currents for cathode positions located closest to the anode. The data in Table 1 show that the current increased linearly with the concentration of $\mathrm{Cu}^{2+}$ ions when the same positions on the electrode are compared.

\section{Experiments with 10 segment planar carbon cathodes}

The current passing through each segment of the carbon electrode was calculated from the voltage drop across the $1 \Omega$ resistor connected to each electrode in parallel with the negative current feeder. As with the nonsegmented carbon electrode described in the previous section, the potential of each electrode was monitored via 10 Luggin capillaries positioned close to their surface. Figure 3 shows the current $v$. potential curves obtained from the static and stirred solutions respectively, during the reduction of $\mathrm{Cu}^{2+}$ ions at a $50 \mathrm{mmol} \mathrm{dm}{ }^{-3}$ concentration. In the static solution (Fig. $3 a$ ), the mass transport region can be clearly seen for all segments of the cathode in the potential rang from $-0 \cdot 3$ to $-0 \cdot 7 \mathrm{~V}(\mathrm{SCE})$ with current values for each electrode between -9 and $-13 \mathrm{~mA}$. The difference between this plot and that obtained for the static solution with a continuous carbon plate electrode, as shown in Fig. $2 a$, is that the currents in each electrode were measured individually. This allows the current at different positions of the cathode to be calculated as a fraction of the total current. Each segment of the

Table 1 Current and cathode potential values for deposition of copper, in mass transport controlled region, at planar carbon electrode

Planar carbon plate Luggin capillary position

\begin{tabular}{|c|c|c|c|c|c|c|c|c|c|c|c|}
\hline \multirow[b]{2}{*}{$\begin{array}{l}c, \mathrm{mmol}^{-3} \\
\mathrm{dm}^{-3}\end{array}$} & \multirow[b]{2}{*}{$\begin{array}{l}\text { Flow } \\
\text { conditions }\end{array}$} & 1 & 2 & 3 & 4 & 5 & 6 & 7 & 8 & 9 & 10 \\
\hline & & \multicolumn{10}{|c|}{ Current in the limiting current region (and cathode potential) $-I, \mathrm{~mA}\left[-E_{\mathrm{c}}, \mathrm{mV}(\mathrm{SCE})\right]$} \\
\hline \multirow[t]{2}{*}{50} & Static & $100(375)$ & $100(350)$ & 100 (320) & 105 (290) & $110(280)$ & $110(250)$ & $120(240)$ & $115(230)$ & $120(215)$ & $\begin{array}{l}120 \\
(170)\end{array}$ \\
\hline & Stirred & $110(150)$ & $110(140)$ & $120(130)$ & $150(80)$ & $160(80)$ & $160(70)$ & $180(60)$ & $180(50)$ & $190(25)$ & $\begin{array}{l}200 \\
(15)\end{array}$ \\
\hline \multirow[t]{2}{*}{75} & Static & 130 (295) & $130(290)$ & $140(270)$ & $150(215)$ & $155(210)$ & $160(180)$ & 165 (170) & $170(160)$ & $180(110)$ & $\begin{array}{l}185 \\
(110)\end{array}$ \\
\hline & Stirred & $520(700)$ & $520(670)$ & $560(570)$ & $580(400)$ & $580(400)$ & $580(315)$ & $540(240)$ & $360(250)$ & $580(170)$ & $\begin{array}{l}600 \\
(130)\end{array}$ \\
\hline \multirow[t]{2}{*}{100} & Static & $160(300)$ & $160(280)$ & $180(230)$ & 200 (200) & 200 (180) & 215 (120) & 225 (100) & 230 (110) & $240(45)$ & $\begin{array}{l}240 \\
(45)\end{array}$ \\
\hline & Stirred & $420(550)$ & 420 (530) & $460(400)$ & $510(210)$ & $510(210)$ & 540 (190) & $540(175)$ & 545 (175) & $570(80)$ & $\begin{array}{l}580 \\
(30)\end{array}$ \\
\hline
\end{tabular}


electrode behaves independently and gives rise to a current $v$. potential curve that falls within the similar range of current and potential. The only difference between the segmented electrodes is that those near the anode show longer mass transport controlled regions due to the lower resistance of the electrolyte. Figure $3 b$ shows the current $v$. potential curves when in a stirred electrolyte. Only the cathode segments closest to the anode achieved mass transport conditions, while the electrodes furthest from the anode remain in the charge transfer controlled region at the applied current.

As the electrodes are located further from the anode, the mass transport region becomes shorter and in the case of the electrodes 9 and 10, the mass transport region is difficult to identify. As the concentration increased, similar behaviour was observed throughout the static and stirred solutions with electrodes 9 and 10 unable to achieve mass transport controlled region in the stirred solution. Table 2 shows the approximate values of current and potential at the mass transport controlled region for all the electrodes. When the mass transport region was not present, the values were taken at the maximum current and potential (negative) values were achieved. Table 2 shows that for the $50 \mathrm{mmol} \mathrm{dm}^{-3}$ $\mathrm{Cu}^{2+}$ ions concentration, the individual current of each electrode in the non-stirring solution was evenly distributed, however; in the stirred solution the electrodes near the anode draw larger currents. This is probably due to the non-uniform stirring conditions used and the geometry of the Hull cell which favours turbulence in areas nearer to anode and at the centre of the cathode while at the corner of the cell, the furthest from the anode, the stirring is low. At higher $\mathrm{Cu}^{2+}$ concentrations, the current distribution favoured the segment electrodes close to the anode in both, static and stirred solutions.

\section{Experiments with single piece (continuous) reticulated vitreous carbon as cathode}

The electrode used in this experiment showed deposits of metallic copper in a short period of time due to the high current imposed. Only the parts of the electrode located at positions 1-5 were completely covered when the concentration of copper was $100 \mathrm{mmol} \mathrm{dm}^{-3}$. At lower $\mathrm{Cu}^{2+}$ ion concentrations of $50 \mathrm{mmol} \mathrm{dm}{ }^{-3}$, positions $1-5$ and 7 were only covered with a thin uniform layer of copper. Figure 4 shows SEM images of copper deposition on the RVC; Fig. $4 a$ shows no copper nucleation on position 10 while position 1 in Fig. $4 f$ clearly shows large dendritic copper deposition. Figure $4 b$ shows nucleation of copper on electrode 9 at $10 \mathrm{~mA} \mathrm{~cm} \mathrm{~cm}^{2}$, Fig. $4 c$ shows smooth copper deposition on electrode 7 at $20 \mathrm{~mA} \mathrm{~cm}$, Fig. $4 d$ shows the bulk deposition of copper with localised nodules at position 3 at $70 \mathrm{~mA} \mathrm{~cm}$, Fig. $4 e$ shows a cauliflower-like structures due to high localised current density at the nodules on position 2 at $80 \mathrm{~mA} \mathrm{~cm}{ }^{2}$ and Fig. $4 f$ shows dendrites of copper on position 1 at $110 \mathrm{~mA} \mathrm{~cm}$.

\section{Experiments with 10 segment reticulated carbon vitreous cathodes}

These electrodes were also attached to the Bakelite back plate support and connected in the same way as the 10 segment planar electrodes described in the previous section. Figure 5 shows the current $v$. potential curves of

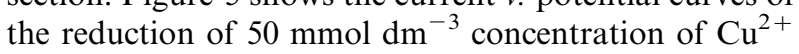
ions at static and stirred conditions respectively. Similar to the planar segmented electrodes, the RVC electrodes behave independently and show their characteristic current $v$. potential curves as a function of the distance from the anode. In the static solution, Fig. $5 a$ shows that the mass transport region was achieved in electrodes $1-6$, while at the electrodes $7-10$, the current was lower and the potentials remained in the mixed potential region at values of $-0 \cdot 15 \mathrm{~V}(\mathrm{SCE})$. When the solution was stirred (Fig. 5b), electrodes 1-6 (near to the anode) showed larger currents and more negative cathode potentials in comparison with those far from the anode (electrodes 7-10). No clear mass transport controlled region was observed under these conditions.

From the current $v$. potential curves (not shown) in the static solution containing $75 \mathrm{mmol} \mathrm{dm}{ }^{-3}$ of $\mathrm{Cu}^{2+}$, the mass transport controlled region can be observed for the electrodes $1-5$ but not for the electrodes 6-10. In the stirred solutions containing 75 and $100 \mathrm{mmol} \mathrm{dm}^{-3}$ $\mathrm{Cu}^{2+}$, the mass transport controlled region is difficult to distinguish and in most cases, the potential increased linearly with the current due to the $I R$ drop in the electrolyte and between the reticulated vitreous carbon electrode and the carbon plate current collector. Table 3 shows that with this electrode configuration, in the static solutions that showed mass transport region (50 and $75 \mathrm{mmol} \mathrm{dm}{ }^{-3}$ ), the current decreased as the distance from the anode increased. In the other cases, in the static

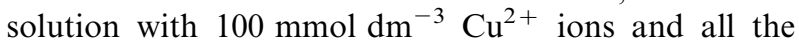
stirred solutions at the three concentrations studied, the current also decreased with the distance from the anode and the potential became more positive.

\section{Electrolysis to calculate plating efficiency}

A constant current electrolysis of a solution containing $50 \mathrm{mmol} \mathrm{dm}{ }^{-3} \mathrm{Cu}^{2+}$ ions was carried out at $-0 \cdot 110 \mathrm{~A}$

Table 2 Approximate current and cathode potential values for deposition of copper in mass transport controlled region for segmented planar carbon plate electrodes

Segmented carbon plate Luggin capillary position

\begin{tabular}{|c|c|c|c|c|c|c|c|c|c|c|c|}
\hline \multirow[b]{2}{*}{$\begin{array}{l}c, \mathrm{mmol}^{-3} \\
\mathrm{dm}^{-3}\end{array}$} & \multirow[b]{2}{*}{$\begin{array}{l}\text { Flow } \\
\text { conditions }\end{array}$} & 1 & 2 & 3 & 4 & 5 & 6 & 7 & 8 & 9 & 10 \\
\hline & & \multicolumn{10}{|c|}{ Current in the limiting current region (and cathode potential) $-I, \mathrm{~mA}\left[-E_{\mathrm{c}}, \mathrm{mV}(\mathrm{SCE})\right]$} \\
\hline \multirow[t]{2}{*}{50} & Static & $10(420)$ & $10(390)$ & $10(415)$ & $10(460)$ & $10(415)$ & $10(370)$ & $10(410)$ & $10(420)$ & $10(410)$ & $12(360)$ \\
\hline & Stirred & $20(200)$ & $16(190)$ & $15(260)$ & $15(180)$ & $10(160)$ & $10(150)$ & $10(170)$ & $10(140)$ & 7 (115) & 7 (80) \\
\hline \multirow[t]{2}{*}{75} & Static & $15(340)$ & 15 (310) & $15(320)$ & $15(330)$ & $15(290)$ & $15(320)$ & $15(360)$ & 15 (280) & $10(115)$ & 7 (110) \\
\hline & Stirred & 40 (310) & 30 (290) & 25 (220) & 30 (190) & 15 (170) & 15 (130) & 15 (120) & 15 (120) & $10(100)$ & 7 (70) \\
\hline \multirow[t]{2}{*}{100} & Static & $25(610)$ & $30(700)$ & $30(655)$ & $30(640)$ & $30(580)$ & 25 (480) & $20(210)$ & 15 (190) & $15(200)$ & 15 (180) \\
\hline & Stirred & $40(270)$ & $30(300)$ & $30(250)$ & $26(150)$ & 25 (180) & $20(150)$ & $20(140)$ & 15 (150) & $10(100)$ & $8(65)$ \\
\hline
\end{tabular}



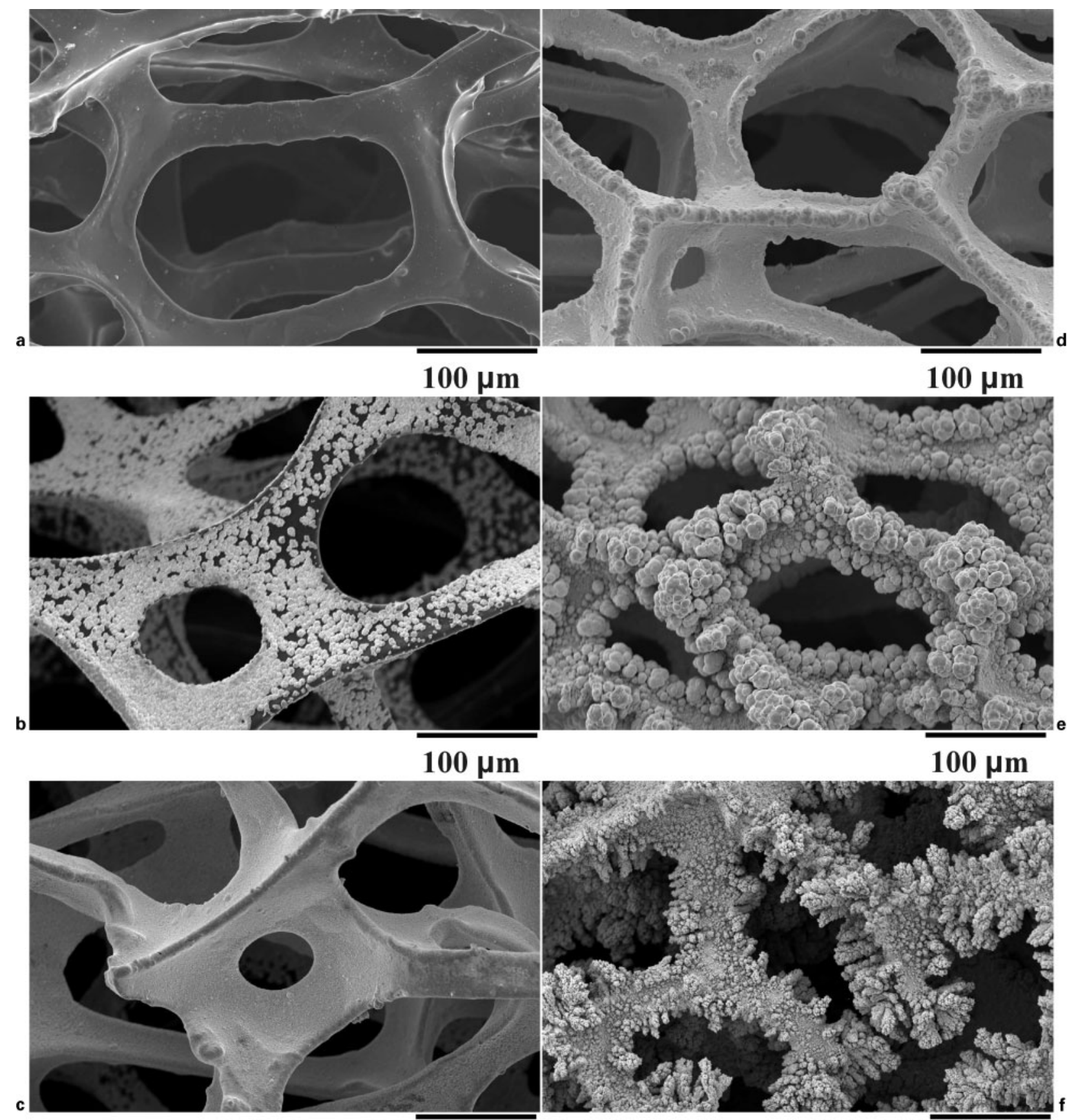

$100 \mu \mathrm{m}$

\section{$100 \mu \mathrm{m}$}

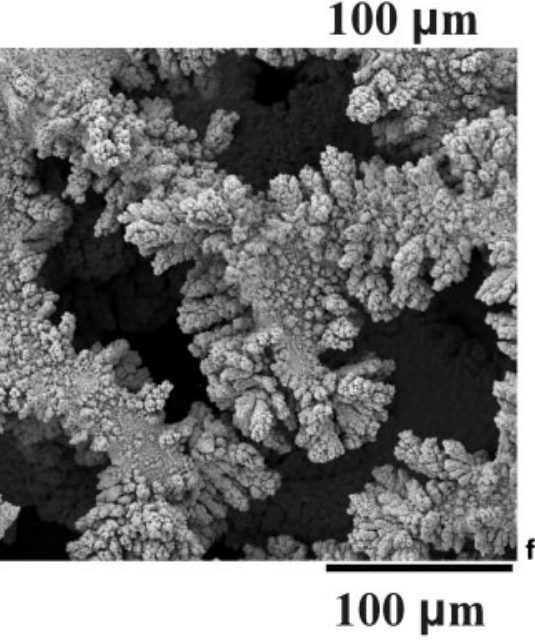

a position 10 showing no copper deposit at $1 \mathrm{~mA} \mathrm{~cm}$; $b$ nucleation of copper on position 9 at $10 \mathrm{~mA} \mathrm{~cm}{ }^{2}$; $c$ smooth deposition of copper on position 7 at $20 \mathrm{~mA} \mathrm{~cm}$; $d$ bulk deposition with localised nodules of copper on position 3 at $70 \mathrm{~mA} \mathrm{~cm}$; e nodular formation ('cauliflower' structures) of copper on electrode 2 at $80 \mathrm{~mA} \mathrm{~cm}$; $f$ copper dendrite formation at position 1 at $110 \mathrm{~mA} \mathrm{\textrm {cm } ^ { 2 }}$

4 Scanning electron micrographs showing copper deposition on RVC electrode using $50 \mathrm{mmol} \mathrm{dm}^{-3} \mathrm{Cu}^{2+}$ in $0.5 \mathrm{~mol} \mathrm{dm}^{-3} \mathrm{Na}_{2} \mathrm{SO}_{4}$ at $\mathrm{pH} 2$ solution at various segmented electrodes and various applied currents after 30 min electrolysis

on a segmented planar carbon and reticulated vitreous carbon electrodes at stirring conditions over $20 \mathrm{~min}$. The current passed through each electrode was monitored $v$. time by measuring the potential drop across a $1 \Omega$ shunt connected to each electrode in series (Fig. 1). At the end of the electrolysis, the deposited copper on each segmented electrode was redissolved in $25 \mathrm{~cm}^{3}$ of $1 \mathrm{~mol} \mathrm{dm}{ }^{-3} \mathrm{HNO}_{3}$ solution at $298 \mathrm{~K}$ and diluted to a concentration range between 0 and $6 \mathrm{ppm}$. The exact value was determined by atomic absorption spectroscopy. The amount of copper dissolved was compared with the predicted amount of copper obtained from the current $v$. time curves.

The current involved in copper deposition at each segmented cathode was calculated from Faraday's laws of electrolysis (under constant current conditions) as

$$
w_{\mathrm{Cu}}=\frac{q_{\mathrm{Cu}} M_{\mathrm{Cu}}}{z F}
$$

or 

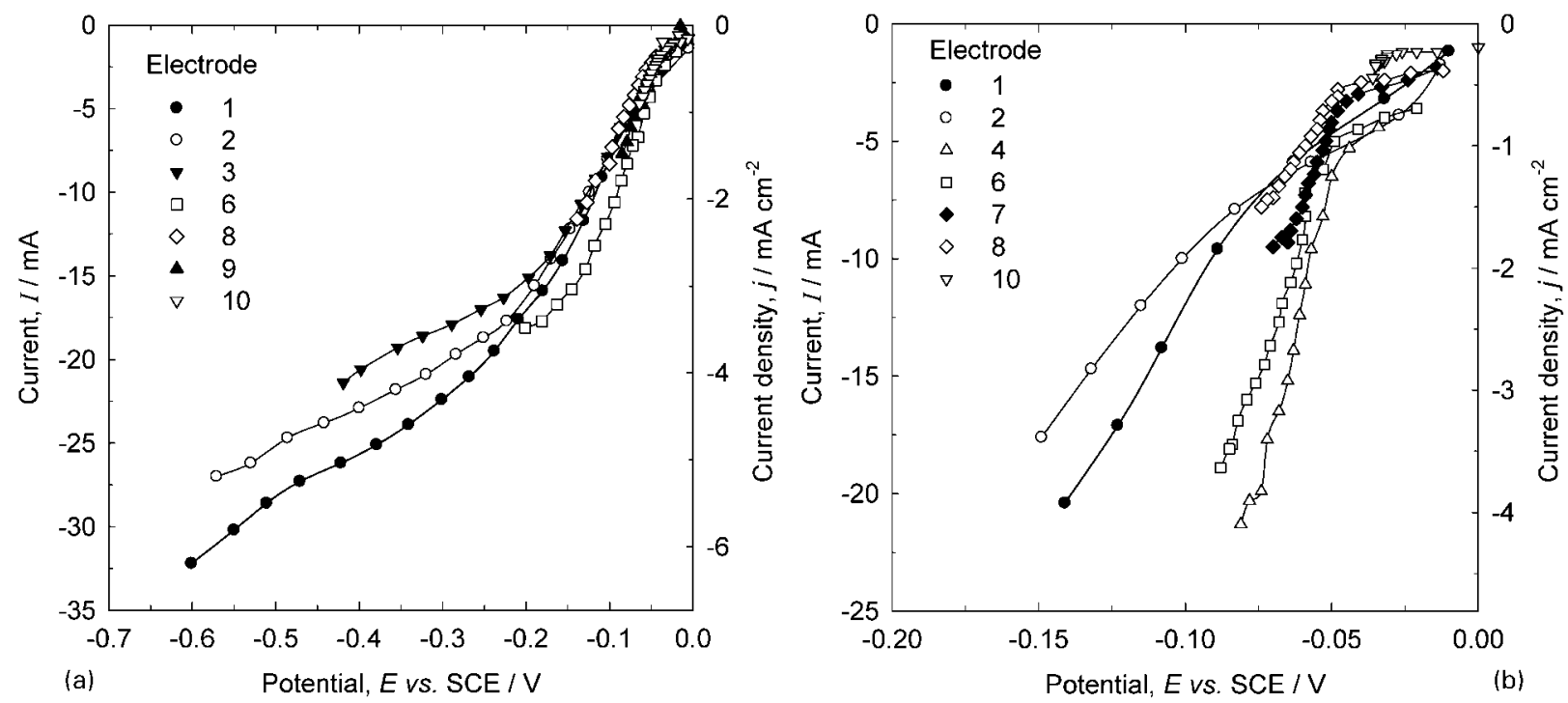

5 Current $v$. potential curves for deposition of $\mathrm{Cu}$ ions from $50 \mathrm{mmol} \mathrm{dm}{ }^{-3} \mathrm{Cu}^{2+}$ in $0.5 \mathrm{~mol} \mathrm{dm}^{-3} \mathrm{Na}_{2} \mathrm{SO}_{4}$ at $\mathrm{pH}_{2}$ on segmented reticulated vitreous carbon electrodes under $a$ static and $b$ stirred electrolyte conditions

$$
w_{\mathrm{Cu}}=\frac{M_{\mathrm{Cu}} I_{\mathrm{Cu}} t}{z F}
$$

The percentage current efficiency for copper deposition can then be estimated as

$$
\begin{aligned}
& \% \phi_{\mathrm{Cu}}=100 \frac{I_{\mathrm{Cu}}}{I} \\
& \% \phi_{\mathrm{Cu}}=100\left(\frac{2 w_{\mathrm{Cu}} F}{M_{\mathrm{Cu}} I t}\right)
\end{aligned}
$$

\section{Planar carbon segmented cathodes}

The electrolysis at a constant current of $110 \mathrm{~mA}$ for $1800 \mathrm{~s}$ should ideally realise a copper deposit weight of $65.2 \mathrm{mg}$ on the entire ten planar segmented electrodes. Figure 6 shows the percentage of this weight of copper deposited on each electrode segment for both planar and RVC cathodes. The data for the planar electrodes show that the first electrode, the nearest to the anode, has lower percentage of copper deposited if compared with electrode 2. This was probably due to problems of surface blockage on this particular electrode. If this electrode is not taken into account for the calculation of the curve, the percentage weight of copper deposited on electrodes 2-9 decays logarithmically with distance

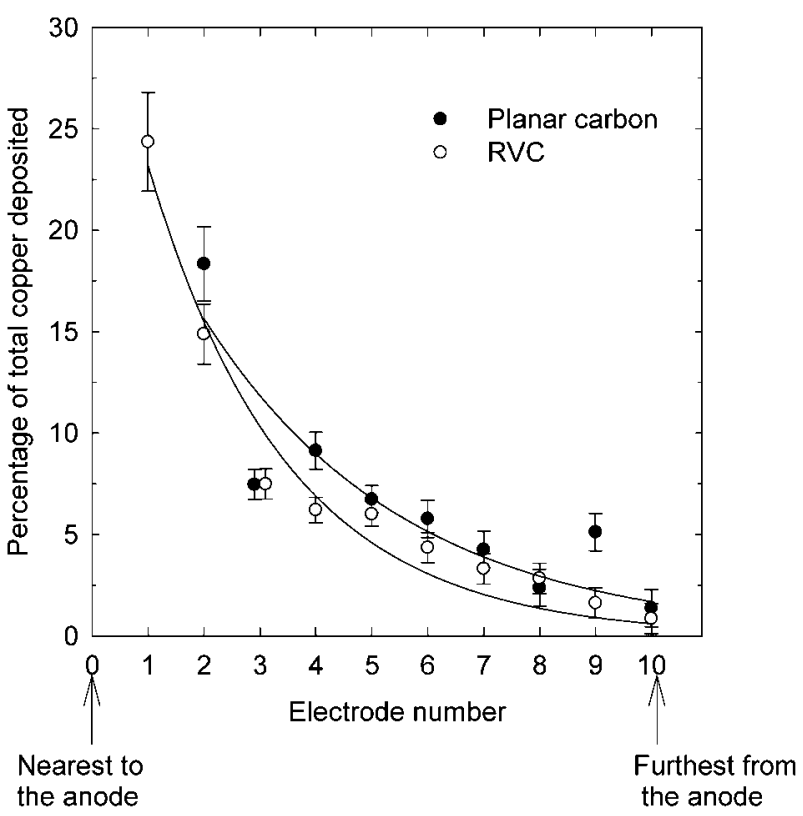

6 Percentage of total copper deposited $v$. electrode number for segmented planar and RVC electrodes: electrolyte was $50 \mathrm{mmol} \mathrm{dm}^{-3}$ of $\mathrm{Cu}^{2+}$ ions in $0.5 \mathrm{~mol} \mathrm{dm}^{-3}$ $\mathrm{Na}_{2} \mathrm{SO}_{4}$ at $\mathrm{pH}$ 2; total current of $110 \mathrm{~mA}$ during $1800 \mathrm{~s}$

\begin{tabular}{|c|c|c|c|c|c|c|c|c|c|c|c|}
\hline \multicolumn{2}{|c|}{$\begin{array}{l}\text { Segmented carbon } \\
\text { plate with RVC }\end{array}$} & \multicolumn{10}{|c|}{ Luggin capillary position } \\
\hline \multirow{3}{*}{$\begin{array}{l}c, \mathrm{mmol}^{-3} \\
\mathrm{dm}^{-3}\end{array}$} & \multirow{3}{*}{$\begin{array}{l}\text { Flow } \\
\text { conditions }\end{array}$} & 1 & 2 & 3 & 4 & 5 & 6 & 7 & 8 & \multirow[t]{3}{*}{9} & \multirow[t]{3}{*}{10} \\
\hline & & 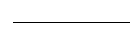 & $\longrightarrow$ & 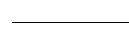 & $\longrightarrow$ & 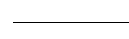 & 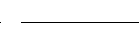 & $\longrightarrow$ & & & \\
\hline & & \multicolumn{8}{|c|}{ Current in the limiting current region (and potential) $-I, \mathrm{~mA}\left[-E_{\mathrm{c}}, \mathrm{mV}(\mathrm{SCE})\right]$} & & \\
\hline \multirow[t]{2}{*}{50} & Static & $25(340)$ & $20(320)$ & $20(290)$ & $15(260)$ & $20(250)$ & $20(200)$ & $15(150)$ & $10(140)$ & $8(90)$ & $5(60)$ \\
\hline & Stirred & 35 (180) & 25 (240) & 35 (190) & $40(160)$ & 40 (180) & 30 (120) & $20(80)$ & $15(90)$ & $8(40)$ & $3(30)$ \\
\hline \multirow[t]{2}{*}{75} & Static & $40(330)$ & $30(310)$ & 35 (190) & $30(270)$ & $30(220)$ & $30(150)$ & $30(100)$ & $15(100)$ & $7(50)$ & $3(40)$ \\
\hline & Stirred & $40(215)$ & $26(240)$ & 35 (200) & $40(160)$ & 40 (180) & 30 (120) & $20(80)$ & $15(90)$ & $8(40)$ & $3(30)$ \\
\hline \multirow[t]{2}{*}{100} & Static & $53(540)$ & $60(530)$ & 45 (430) & $40(240)$ & 40 (190) & $30(140)$ & $25(90)$ & 15 (100) & 7 (55) & $4(40)$ \\
\hline & Stirred & $40(330)$ & $30(250)$ & 35 (355) & $25(170)$ & 25 (190) & 18 (160) & $20(140)$ & 15 (150) & $10(100)$ & $8(65)$ \\
\hline
\end{tabular}

Table 3 Current and potential values for deposition of copper in mass transport controlled region for segmented RVC electrodes 
along the cathode. The current efficiency calculated according to equation (9) on each electrode was always close to $100 \%$.

\section{Segmented reticulated vitreous carbon cathodes}

Figure 6 also shows the data of the percentage of total copper deposited on each segmented RVC electrode. Unlike electrode 1 in the planar configuration, electrode 1 nearest to the anode shows the highest percentage of copper deposited, 24\%. Data for the percentage deposited on each electrode also show a logarithmic distribution decay deposition of copper along the cathode distance. As in the experiment with the segmented planar electrodes, the current efficiency at each electrode was always close to $100 \%$.

Further studies of copper deposition at a Hull cell with a reticulated vitreous carbon cathode from electrolytes containing electroplating additives, e.g. Refs. 39 and 40 , are planned.

\section{Conclusions}

1. This paper has shown a novel application of the Hull cell; using segmented RVC as an electrode material; the electrode can be sectioned rapidly to quantitatively determine the current distribution during copper deposition.

2. The Hull cell allows the determination of effective parameters for electrodeposition both in planar and RVC electrodes. It was shown that for similar currents, both electrodes present a lower potential drop when the solution is agitated and that it is possible to study solutions involving mass transport limiting steps in the Hull cell.

3. The limiting current regions were better defined for the planar plate segmented electrodes than for the segmented RVC and planar plate electrodes. This was showed by graphical comparison of planar plat segmented electrodes with that of a planar carbon cathode and segmented RVC one.

\section{Acknowledgements}

Early trials on a segmented RVC cathode Hull cell were performed by A. Neale at the University of Portsmouth, UK. The authors are grateful to Dr A. Howard (University of Southampton) for expert advice on atomic absorption spectrophotometric analysis and to Dr I. Sirés in the authors' group for his assistance with chemical analysis.

\section{References}

1. F. A. Lowenheim: 'Modern electroplating', 2nd edn, Electrochemical Society Series; 1963, New York, Wiley.

2. I. Rousar, K. Micka and A. Kimla: 'Electrochemical engineering'; 1986, Amsterdam, Elsevier.

3. F. Coeuret, D. Hutin and A. Gaunand: J. Appl. Electrochem., 1976, 6, $417-423$
4. J. A. Trainham and J. Newman: J. Electrochem. Soc., 1977, 124, $1528-1540$.

5. D. A. Cowan and J. H. Brown: Ind. Eng. Chem., 1959, 51, 14451448.

6. M. S. El-Deab, M. M. Saleh, B. E. El-Anadouli and B. G. Ateya: J. Electrochem. Soc., 1999, 146, 208-213.

7. M. Matlosz and J. Newman: J. Electrochem. Soc., 1986, 133, 1850 1859.

8. J. S. Newman and C. W. Tobias: J. Electrochem. Soc., 1962, 109, 1183-1191.

9. Y. Fujiwara, M. Izaki, H. Enomoto, T. Nagayama, E. Yamauchi and A. Nakae: J. Appl. Electrochem., 1998, 28, 855-862.

10. R. W. Houghton and A. T. Kuhn: J. Appl. Electrochem., 1974, 4, 173-190.

11. Y. Assaf: Met. Finish., 2002, 100, 12, 14

12. S. Robertson, M. Jeffrey, H. Zhang and E. Ho: Metall. Mater. Trans. B, 2005, 36B, 313-325.

13. E. S. Man, E. E. Farndon, S. A. Campbell and F. C. Walsh: Trans. Inst. Met. Finish., 1996, 74, 39-44.

14. C. Ponce-de-León, C. T. J. Low, G. Kear and F. C. Walsh: J. Appl. Electrochem., 2007, 37, 1261-1270.

15. C. T. J. Low, C. Ponce de Leon and F. C. Walsh: Aust. J. Chem., 2005, 58, 246-262.

16. C. Madore, A. C. West, M. Matloz and D. Landolt: Electrochim. Acta, 1992, 37, 69-74.

17. C. T. J. Low, E. P. L. Roberts and F. C. Walsh: Electrochim. Acta, 2007, 52, 3831-3840

18. C. T. J. Low and F. C. Walsh: Surf. Coat. Technol., 2008, 202, 1339-1349.

19. R. O. Hull: Monthly Rev. Am. Electroplat. Soc., 1939, 26, 753-767.

20. D. Pletcher and F. C. Walsh: 'Industrial electrochemistry', 2nd edn; 1993, London, Blackie Academic \& Professional.

21. D. R. Gabe and G. D. Wilcox: Trans Inst. Met. Finish., 1993, 71, 71-73.

22. J. D. Fisk and J. D. Boyle: Trans Inst. Met. Finish., 2000, 78, 113119.

23. R. Renuka, S. Ramamurthy and K. Muralidharan: J. Power Sources, 1998, 76, 197-209.

24. Z. Zhang, J. Q. Zhang, W. H. Leng and C. N. Cao: J. Electrochem. Soc., 2001, 148, C488-C491.

25. F. C. Walsh and G. W. Reade: 'Environmental oriented electrochemistry', (ed. C. A. C. Sequeira), 3; 1994, Amsterdam, Elsevier.

26. D. Simonsson: Chem. Soc. Rev., 1997, 26, 181-189.

27. F. C. Walsh and G. W. Reade: 'Electrochemistry for a cleaner environment', (eds. J. D. Genders and N. L. Weinberg), 393; 1983, London, Plenum.

28. J. Wang: Electrochim. Acta, 1981, 26, 1721.

29. C. Ponce-de-León and D. Pletcher: Electrochim. Acta, 1996, 41, 533-541.

30. G. Carreño, E. Sosa, I. González, C. Ponce-de-León, N. Batina and M. T. Oropeza: Electrochim. Acta, 1999, 44, 2633-2643.

31. D. Pletcher, I. Whyte, F. C. Walsh and J. P. Millington: J. Appl. Electrochem., 1991, 21, 667-671.

32. D. Pletcher, I. Whyte, F. C. Walsh and J. P. Millington: J. Appl. Electrochem., 1993, 23, 82-85.

33. J. M. Friedrich, C. Ponce-de-León, G. W. Reade and F. C. Walsh: J. Electroanal. Chem., 2004, 561, 203-217.

34. E. Raub and K. Muller: 'Fundamentals of metal deposition'; 1967, New York, Elsevier.

35. T. D. McColm and J. W. Evans: J. Appl. Electrochem., 2001, 31, 411-419.

36. C. Muller, M. Sarret and T. Andreu: J. Electrochem. Soc., 2002, 149, C600-C606.

37. Y. Fujiwara, M. Izaki, H. Enomoto, T. Nagayama, E. Yamauchi and A. Nakae: J. Appl. Electrochem., 1998, 28, 855-862.

38. E. Binkauskene: Russ. J. Appl. Chem., 2002, 75, 852-853.

39. S. A. Campbell, E. E. Farndon, F. C. Walsh and M. Kalaji: Trans. Inst. Met. Finish., 1997, 75, 10-17.

40. E. E. Farndon, F. C. Walsh and S. A. Campbell: J. Appl. Electrochem., 1995, 25, 574-583. 